\section{Financial planning}

\begin{abstract}
An impasse over the budget and the impending presidential election mean that US science spending will likely be frozen for months, David Goldston reports.
\end{abstract}

W ashington DC in August is always a picture of torpor. The humidity rises and Congress escapes for a month-long recess, slowing the pace of work for everyone from Cabinet officials to taxi drivers. But this year, life is even more sluggish than usual, as work on the federal budget has come to a virtual standstill.

Normally, beneath the dormant surface, crucial work on the budget gets done in August. If this were a typical year, agencies would be preparing their spending plans for fiscal year 2010 , inaugurating a process that culminates with the president's budget submission to Congress in February. And House and Senate staff would be starting to work out agreements on disputed items for fiscal year 2009, which begins on 1 October. The White House Office of Management and Budget (OMB), the relatively small but powerful unit that oversees budget preparation, would be monitoring and influencing the activities of both the executive and legislative branches. This year, budget staff can pretty much go on holiday like everybody else.

This is not politics as usual. Breaking with precedent, the Bush administration has decided not to prepare a budget for fiscal 2010, given that it will not be in office to either fight for or implement the proposal. In the past, outgoing administrations have left behind a budget as a kind of marker, a last attempt to have an impact on debate. More significantly, the Democratic leaders of Congress have decided to wait until after a new president takes office on 20 January to complete action on the spending bills for 2009, except those for homeland security and defence. As a result, federal agencies, including all the civilian science agencies, will probably have their spending frozen at current levels for at least the first four months of the fiscal year.

At first blush, this is bad news for research funding. Under the current House and Senate versions of the fiscal 2009 spending bills, the major science agencies would receive sizable increases on 1 October. The National Science Foundation, for example, would see its budget jump by about $13 \%$ over current levels. But these numbers would probably fall prey to larger budget concerns, as they did last year (see Nature 449, 962; 2007), if Congress tried to enact them with President Bush still in office. The Democrats want to spend $\$ 21$ billion more

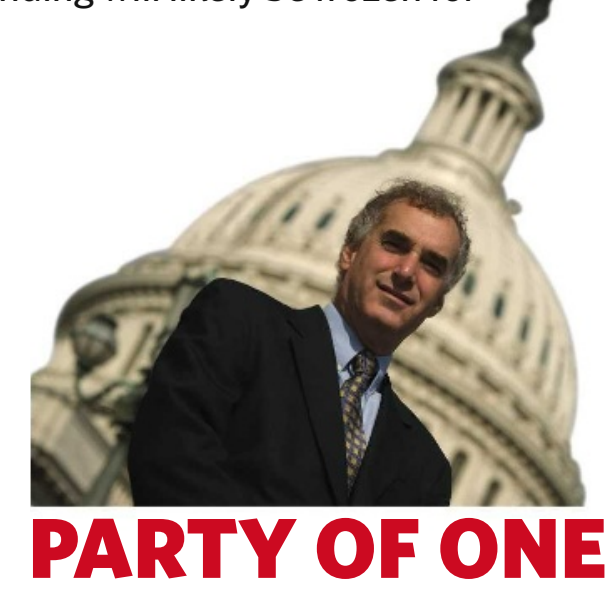

on domestic programmes than the president has proposed, and Bush has threatened to veto any measure that exceeds his request.

This is the same impasse that emerged at this time last year. The Democrats found out then that they couldn't overcome Bush's determination, despite his sinking popularity. Presidents almost always have the advantage in this kind of test of wills. The legislative process, even at its best, looks messy and confused and involves many voices. The President has easy access to the media and can seem to be above the fray. Moreover, Congress's own popularity ratings have been low. In the end, last year, the Democrats capitulated and accepted the president's overall spending number, dragging science funding down with the total.

The congressional leaders are wise to conclude that the outcome would probably be no different this time. And the Democrats would be just as unlikely this year to find a way to protect science funding if they had to slice $\$ 21$ billion from their spending plans without doing violence to their other priorities. So the National Science Foundation and the other agencies might actually be better off with a freeze for the first part of the year, if it means that a big increase is more likely to materialize once a new administration is installed.

Of course, it's not yet clear who the next president will be or what budget he will propose. The Democrats' presumed candidate, Senator Barack Obama of Illinois, has explicitly endorsed doubling funding for basic research (his website doesn't say over what time period), but he has also called for reducing the national debt and offsetting spending increases with cuts elsewhere or with increased revenues. His presumed opponent, Senator John McCain of Arizona, has called for more spending on biomedical research and has supported science spending as a senator; but he has also called for a one-year spending freeze to figure out how to eliminate the federal deficit by 2013. And whoever wins is likely to face a faltering economy and a record federal deficit that could make it harder to raise spending, even for relatively small accounts like most of the science agencies.

Moreover, the new president won't have much time to figure out how to proceed. Thanks to the stand-off between Bush and Congress, he will not only have to swiftly write his 2010 budget proposal, he will also need to make immediate decisions about fiscal 2009. The system simply wasn't meant to operate this way. But then, compromise was supposed to be the lubricant in the US political mechanism, with its distributed powers. The US Constitution, marvelled a nineteenth-century American notable, set up a "machine that would go of itself". Now it's come to a halt, unable to produce its most basic product, the budget, thanks to ideological polarization, political uncertainty, unwillingness to compromise and personal antipathies.

But behind the scenes, key officials are working to make sure the budget machinery can restart quickly in the next administration. The OMB traditionally puts together budget scenarios and options for the incoming president, and this little-known but vital process is already getting under way. OMB director Jim Nussle, a political appointee, has charged all the federal agencies to submit baseline data this autumn, showing what spending would be needed in 2010 to maintain their current activities. OMB staff, who are civil servants, are working with some agencies on preparing a range of budget options; some agencies, such as the Department of Energy, have decided to put together ideas for three types of budgets, ranging from unrealistically generous to absolutely flat. Once the election is over, the OMB will probably ask the agencies to provide numbers for more options, based, remarkably enough, on what the winning candidate said during the campaign.

So the wheels of government are continuing to turn, albeit slowly and quietly and only at the back end of the machinery. It will be at least February and more likely March before any spending instructions come out from the new president and Congress. And whether that budget will imbue scientists with a mood of summery ease or of wintry constriction is still anybody's guess.

David Goldston, former chief of staff for the House Committee on Science, is a visiting lecturer at Harvard University's Center for the Environment. Reach him at partyofonecolumn@gmail.com. 